\title{
INCIDENCE OF POSTPARTUM MOOD DISORDERS DEPENDING ON SELECTED RISK FACTORS - A LOGISTIC REGRESSION MODEL
}

\author{
WYSTĘPOWANIE ZABURZEŃ NASTROJU PO PORODZIE \\ W ZALEŻNOŚCI OD WYBRANYCH CZYNNIKÓW RYZYKA \\ - MODEL REGRESJI LOGISTYCZNEJ
}

${ }^{1}$ Nicolaus Copernicus University in Torun, Faculty of Health Sciences, Collegium Medicum in Bydgoszcz

S u m m a r y

The aim of the study was to assess the severity of mood disorders in women in the first and sixth week postpartum and to determine the incidence of baby blues depending on selected risk factors.

Material and methods. 285 postpartum women were enrolled in the study. The research project was divided into two stages (first and sixth week postpartum). The Edinburgh Postnatal Depression Scale (EPDS) was used to assess the severity of mood disorders. The indicator of the presence of disorders was set at $\geq 12$ points on the 30 -point EPDS scale. In order to determine the impact of selected independent variables on the dichotomous dependent variable (baby blues), a logistic regression model was used based on the following formula:

$$
P(1)=\frac{e^{-1.474+0.938 \text { Fin.prob.1.657Nohelp }+1.352 \text { Psych.dis. }}}{1+e^{-1.474+0.938 \text { Fin.prob. }+1.657 \text { Nohelp }+1.352 \text { Psych.dis.. }}}
$$

R e s u l t s . In the first week postpartum, baby blues was found in $23.2 \%$ of the postpartum women. The risk for postnatal depression after six weeks postpartum was determined in $17.3 \%$ of the women. The odds ratio for baby blues correlated with: unfavorable financial situation of the women $(\mathrm{OR}=2.56)$, a family history of mental disorders $(\mathrm{OR}=3.87)$, and dissatisfaction with medical care received during childbirth $(\mathrm{OR}=5.24)$.

Conclusions

1. Cases of baby blues were determined in every fourth woman from the sample group.

2. The risk for postnatal depression was found in $17.3 \%$ of women after six weeks postpartum.

3. The odds ratio for baby blues was affected by the following statistically significant factors: unfavorable financial situation of the women, genetic predispositions and dissatisfaction with perinatal medical care.

\section{Streszczenie}

Celem badania była ocena nasilenia zaburzeń nastroju u kobiet w 1 tygodniu i 6 tygodni po porodzie oraz ustalenie prawdopodobieństwa wystąpienia przygnębienia poporodowego w zależności od wybranych czynników ryzyka.

Materiał i metody. Do badania włączono 285 kobiet po porodzie. Projekt badawczy przeprowadzono w dwóch etapach (1 i 6 tydzień po porodzie). Do oceny nasilenia zaburzeń nastroju wykorzystano Edynburską Skalę Depresji Poporodowej (EPDS). Za wskaźnik zaburzeń przyjęto $\geq 12$ punktów w 30 stopniowej skali EPDS. W celu ustalenia wpływu wybranych zmiennych niezależnych na dychotomiczną zmienną zależną (przygnębienie poporodowe) wykorzystano model regresji logistycznej o wzorze:

$$
P(1)=\frac{e^{-1.474+0.938 \text { Klop. fin.+1.657Brak pomocy }+1.352 \text { Ch. psych. }}}{1+e^{-1.474+0.938 \text { Klop.fin. }+1.657 \text { Brak pomocy }+1.352 \text { Ch.psych. }}}
$$

Wyniki. W 1 tygodniu po porodzie przygnębienie poporodowe odnotowano u $23,2 \%$ położnic. Ryzyko wystąpienia depresji poporodowej po 6 tygodniach od 
urodzenia dziecka stwierdzono u 17,3\% kobiet. Prawdopodobieństwo wystąpienia baby blues było związane: $\mathrm{z}$ niekorzystną sytuacją finansową kobiet $(\mathrm{OR}=2,56), \mathrm{z}$ rodzinną historią chorób psychicznych $(\mathrm{OR}=3,87)$ i niezadowoleniem $\mathrm{z}$ opieki medycznej podczas porodu (OR=5,24).

Wnioski

1. Przygnębienie poporodowe $\mathrm{w}$ badanej próbie dotyczyło co czwartej położnicy.
2. Ryzyko wystąpienia depresji poporodowej stwierdzono u $17,3 \%$ kobiet po 6 tygodniach od urodzenia dziecka.

3. Na prawdopodobieństwo wystąpienia przygnębie-nia poporodowego w badanej próbie kobiet miały istotny statystycznie wpływ następujące czynniki: niekorzystna sytuacja materialna kobiet, uwarunko-wania genetyczne i niezadowolenie $\mathrm{z}$ opieki medycznej podczas porodu.

Key words: puerperium, baby blues, postpartum depression, Edinburgh Postnatal Depression Scale Stowa kluczowe: połóg, baby blues, depresja poporodowa, Edynburska Skala Depresji Poporodowej

\section{INTRODUCTION}

Depression occurs in women of all ages. Today, however, cases of postnatal depression receive special attention, since its insidious nature may lead to major problems in private and family life. Channi Kumar, an outstanding researcher of women's mental health, stated in the 1980s that postpartum depression is of seemingly minor clinical significance, especially when compared with more severe psychiatric disorders. On the other hand, the same researcher noticed that mental crises related to childbirth occur 100 times more frequently than in other stages of a woman's life, which is why they deserve special attention of medical personnel [1].

In everyday language, the word "depression" is commonly used to describe malaise, depressed mood, gloom, and sadness - irrespectively of the causes of such states. In psychiatry, the word "depression" concerns a particular kind of mood and emotional disorders, namely those which can be considered a disease. Ordinary states of despondency are shorter, low mood is not as intense, sleep disorders and mood swings do not occur [2]. Identification of postpartum psychiatric disorders presents numerous theoretical and practical difficulties. Scientists have not, as yet, managed to differentiate postpartum depression from depressions occurring in other stages of a woman's life. Many of somatic symptoms of depression, such as poor appetite, sleep disorders, and hypoactive sexual desire, may occur during the normal process of adaptation after childbirth [3]. Psychiatric disorders occurring after childbirth are usually of affective nature [2].

In the 1980s, Hopkins and co-authors [4] distinguished three forms of clinical depressive states after childbirth: postpartum blues, postpartum depression, and postpartum psychosis. The said disorders differ with respect to the types and intensity of symptoms as well as the time of occurrence and duration. Recent studies have shown that postpartum psychiatric disorders in women encompass numerous different diseases which may be similar to depression, but have different etiology and often require different treatment regimens. Post-traumatic stress disorder, panic disorder, obsessive-compulsive disorder, dysmorphobia, sleep disorders, disruption of emotional relationship between mother and child, as well as recurring feelings of anger and disappointment are just a few examples [5].

The least severe form of postpartum mood disorders is baby blues. It is relatively short and mild, and occurs immediately after childbirth, usually within the first three days. Baby blues is experienced by roughly $85 \%$ of mothers [6]. Women tend to be tearful, irritated, and unable to focus. Such changes are sometimes regarded as a natural consequence of a rapid drop in the concentration of estrogen, progesterone, and cortisol [1]. Severe, persistent postpartum sadness may develop into postpartum depression [7].

Postpartum depression is the most common form of psychiatric disorders occurring after childbirth. Its severity may range from acute and psychotic to mild and chronic. In one in three cases, it is preceded by postpartum blues which is gradually developing [1] Postpartum depression is usually defined as a major depressive episode which occurs during the first four weeks after childbirth, according to DSM-IV, or the first six weeks, according to ICD-10 [8]. According to diagnostic criteria, in order to be diagnosed with major depressive disorder, a person has to manifest at least five out of nine possible symptoms, with at least one of them being either depressed mood or decreased interest and pleasure. Symptoms connected with behavioral disorders, such as changes in appetite, energy, and sleep, illustrate the impact of depression on the organism as a whole. Symptoms have to persist for at 
least two weeks for the disorder to be considered a depression [9]. The considerable frequency of occurrence of postpartum depression in women of various cultural backgrounds makes this disorder a global problem [8]. Postpartum depression concerns $10-20 \%$ of women [10]. According to Fisher and coauthors [11], it occurs at the frequency of over $30 \%$. The clinical picture of depression is similar to that of a depressive episode in recurrent depressive disorder, the similarities being: depressed mood, anhedonia, general anxiety, excessive worry about the child, depressive delusions connected with the feeling of guilt, insomnia, thoughts of resignation and suicide [12]. One of the biggest research study concerning suicidal behaviors in women diagnosed with postpartum depression, carried out by Howard and co-authors [13] on a cohort of 4150 mothers, showed that $4 \%$ of the women experienced suicidal thoughts either "sometimes" or "quite often", whereas $9 \%$ of them experienced such thoughts only once.

A psychiatric emergency accompanied by particularly violent symptoms is characterized as postpartum psychosis. The disorder manifests itself with such symptoms as: disorganized thinking, delusions of persecution or reference, visual, olfactory and somatic hallucinations, lack of insight, cognitive impairment, and infanticide thoughts or tendencies [8]. Postpartum psychosis occurs at the frequency of 0.1 $0.2 \%$ [14]. It can develop during the first two weeks after childbirth. Postpartum psychotic state unquestionably requires specialized treatment [8].

Normal pregnancy and childbirth per se are never a cause of depressive disorders. They may, however, trigger the occurrence of certain factors which may induce postpartum psychiatric disorders. A mother's young age, low socioeconomic status, single parenthood, and lack of support from the partner are crucial demographic and psychosocial risk factors for the occurrence of postpartum depression [8]. Bloom and co-authors [15] conducted a study on 4941 women and found that preeclampsia, hospitalization during pregnancy, emergency caesarean section, high-risk pregnancy, and newborn hospitalization double the chance of occurrence of postpartum depression. According to a study by Mori and co-authors [16], previous episodes of affective disorders come to the fore among psychiatric risk factors. According to Payne and co-authors [17], women living in families with a history of psychiatric disorders have a higher risk of suffering from postpartum depression.
AIM

The aim of the study was to assess the intensification of mood disorders in women in the first and sixth week postpartum and to determine the incidence of baby blues depending on selected risk factors.

\section{METHODS AND MATERIAL}

The study included 285 women after childbirth. The project was carried out under permission of the Bioethics Committee (no. KB 271/2010). The women gave written consent to participate in the two-stage study. The first stage of the study enrolled 285 women at a mean of 3 days after delivery, staying in an Obstetric Care Ward. The second stage of the study (6 weeks postpartum) was carried out by means of a postal survey and included 185 women. The Edinburgh Postnatal Depression Scale was posted to the home addresses of 285 women in the sixth week postpartum, requesting that they fill out the questionnaire once again and return it to the researcher's address (185 replies with the EPDS form were received).

The Edinburgh Postnatal Depression Scale (EPDS) was used to assess the intensification of the symptoms of postpartum mood disorders. The indicator of the presence of disorders was set at $\geq 12$ points on the 30 point EPDS scale. Moreover, a survey questionnaire of own design and medical records were used for the purposes of the study. The questionnaire comprised demographic questions concerning sociodemographic information (age, educational attainment, marital status, economic situation, professional activity, relations with husband/partner), as well as closedended, semi-open and filter questions concerning the course of pregnancy, labor, and puerperium, and potential risk factors for the occurrence of postpartum psychiatric disorders developed on the basis of literature review.

The Edinburgh Postnatal Depression Scale was created by John L. Cox, Jennifer M. Holden, and Ruth Sagovsky in 1987 in Livingston and Edinburgh. It is a self-rating questionnaire whose aim is to detect depressive symptoms. It consists of 10 short questions, each of which is answered by a woman by choosing an option that best describes her feelings during the past 7 days. Obtaining a threshold score (12 to 13 points out of 30) indicates the "probability" of suffering from depressive disorders of various intensity [18]. It is 
important to remember, though, that a high score does not equal a definite diagnosis of depression, since the final diagnosis depends on medical examination and diagnostic criteria.

Data obtained from the questionnaire of own design, the EPDS scale and medical records were subjected to statistical analysis using tools available in Microsoft Office Excel 2000 and the STATISTICA v.10 software. The following statistical methods were used: student's t-test, two-proportion test and logistic regression analysis. In order to test the working hypotheses, $\mathrm{p}=0.05$ was set as a reliable level of statistical significance, for which critical values were given. To determine which independent variables affect the occurrence of the dichotomous dependent variable, a model of logistic regression was built and verified. Mood disorders are the dependent variable ( 0 - no baby blues, 1 - presence of baby blues). In the first stage of the study, the following independent variables were included which may trigger the occurrence of postpartum mood disorders (baby blues):

- marital status (1 - single, 2 - in a relationship),

- economic situation (0 - good, 1 - unfavorable),

- $\quad$ preterm birth (0 - no, 1 - yes),

- lactation problems (0 - no, 1 - yes),

- absence of significant others during labor (0 no, 1 - yes),

- $\quad$ support from medical personnel during labor (0 - help, 1 - no help),

- history of psychiatric disorders in family (0 no, 1 - yes),

- negative life events in the course of pregnancy $(0-$ no, 1 - yes $)$.

To analyze the influence of selected factors on the probability of occurrence of psychiatric disorders, the following model was created:

$$
P\left(\text { Fakt }=1 \mid x_{1}, x_{2}, \ldots, x_{k}\right)=\frac{e^{a_{0}+\sum_{i=1}^{k} a_{i} x_{i}}}{1+e^{a_{0}+\sum_{i=1}^{k} a_{i} x_{i}}}
$$

where: $x_{1}, x_{2}, \ldots, x_{\mathrm{k}}-$ selected factors (independent variables),

$a_{\mathrm{i}, \mathrm{i}=0, \ldots, \mathrm{k}}-$ the sought regression coefficients

The estimation of logistic regression equation for the selected parameters was performed using the iterative quasi-Newton method. To calculate the loss function, a method of the highest credibility was used. The iterative method consists in a successive elimination of parameters determined as irrelevant. Relatively small confidence intervals for the estimators of model parameters $(-95 \% \mathrm{CL},+95 \% \mathrm{CL})$ indicate that the selected model is well suited for the empirical data. The logistic regression model has the following form:

$$
P(1)=\frac{e^{-1.474+0.938 \text { Fin.prob }+1.657 \text { No help }+1.352 \text { Psych.dis. }}}{1+e^{-1.474+0.938 \text { Fin.prob. }+1.657 \text { Nohelp }+1.352 \text { Psych.dis.. }}}
$$

where: Fin.prob. - unfavorable financial situation No help - dissatisfaction with support received during childbirth

Psych.dis. - a family history of psychiatric disease

The above model illustrates the correlation of postpartum mood disorders (baby blues) with crucial parameters. Positive values of regression coefficients indicates that the odds ratio for the disorders increases with a given parameter increasing from 0 to 1 . The absolute value of the regression coefficient demonstrates the effect of a given parameter on the occurrence probability of mood disorders.

\section{RESULTS}

The mean age of women in the study group was 29 (28.55) years of age with a standard deviation of 5 years $(\mathrm{SD}=4.81)$. One out of ten respondents confessed that she had financial problems, whereas the vast majority (90\%) described their economic situation as at least decent. $44.6 \%$ of the women had a higher education degree and $36.1 \%$ finished only secondary school. Women with primary or vocational education constituted a definite minority. Most of the women were married $(75.1 \%) .23 .5 \%$ of the women experienced at least one negative life event in the course of pregnancy. A slight majority of the respondents $(64.6 \%)$ went through labor accompanied by a significant other. During the medical historytaking, $6.7 \%$ of the women confessed that they had suffered from a psychiatric disorder before pregnancy. The gathered data revealed that the families of $4.6 \%$ of the women had a history of psychiatric disorders. $3.8 \%$ of the women expressed dissatisfaction with medical care received during childbirth.

Obtaining a score of 12 or more points in the Edinburgh Postnatal Depression Scale was indicative of mood disorders. The first measurement of the dependent variable was performed at the average of 3 days postpartum $(\mathrm{SD}=1.339)$. The analysis of the gathered data indicates that the average score was 8.15 points in EDPS, with $\mathrm{SD}=5.537$ and median=8. The lowest score obtained was 0 , and the highest was 24 . The average score obtained in the sixth week after 
childbirth was 6.91 points in EDPS, with $\mathrm{SD}=5.63$ and median $=6$. The lowest score obtained was 0 , and the highest was 28. In the first week after childbirth, 66 (23.2\%) women obtained 12 or more points in EPDS. The EDPS questionnaire was filled out usually on the third day puerperium (1st measurement). Therefore it should be stated that the analyzed disorder was baby blues, whose symptoms are most intense between the third and the fifth day after childbirth. According to scientific research, postpartum depression is a continuation of disorders which appear during the first days after childbirth [6].

The table below presents the number and percentage of cases with and without mood disorders measured in a group of 185 women in the first and the sixth week postpartum. Six weeks after childbirth, 32 $(17.3 \%)$ women obtained 12 or more points in EDPS (table I). Although the number of cases of mood disorders in the sixth week after childbirth decreased, the two-proportion test did not find a significant difference. The calculated value of the $u$-statistic is lower than the critical value (1.96, $\mathrm{p}=0.12, \mathrm{~ns})$. Moreover, calculations were performed of mean values of the scores for mood disorders at two points of time, and of the differences (changes) in scores for each woman. It was determined that the mean level of mood disorders in women from the study group $(n=185)$ decreased significantly - the calculated difference is significantly lower than the reference value $(p=0.0003$ for the Student's t-test) - table II.

In the next part of the study, data obtained using EDPS in a group of 185 women in the sixth week postpartum was analyzed. $9.9 \%$ of women who did not manifest symptoms of mood disorders (baby blues) in the first week postpartum obtained mean scores indicating an intensification of depressive disorders in the sixth week after childbirth. $59.1 \%$ of women who suffered from a mood disorder in the first week experienced an improvement of mood in the sixth week. However, out of the 44 women who suffered from baby blues, $40.9 \% \quad(n=18)$ demonstrated symptoms of postpartum depression in the sixth week postpartum (table III). The percentages of improvement and deterioration of depressive moods were thus compared in women in the sixth week postpartum. The likelihood of improvement in the sixth week postpartum $(59.1 \%)$ was found to be significantly higher than the likelihood of worsening (9.9\%): $\mathrm{u}=6.28>\mathrm{u}_{\mathrm{kr}}=1.96, \quad p<0.0001$ for the two-proportion test).
In order to determine possible correlations between the selected independent variables (risk factors) and the dependent variable (baby blues), a multifactorial analysis was carried out using a logistic regression model. The developed model defines the probability of occurrence of baby blues depending on selected correlates. Table IV presents parameters of the model and the results of estimation in the last stage. The Chi square statistic, describing the difference between the considered model and the model with only absolute term, is highly significant $(\mathrm{p}=0.00089)$. Therefore, it can be inferred that a model with such a set of variables is well suited for the data. It can thus be concluded that the odds ratio for baby blues was affected by the following independent variables: unfavorable financial situation of the women, genetic predispositions and dissatisfaction with received perinatal medical care. The calculated probability quotients for the dichotomous parameters are, respectively: $\mathrm{OR}=2.56, \mathrm{OR}=3.87$, and $\mathrm{OR}=5.24$.

\section{DISCUSSION}

Data gathered during the first measurement indicate that the analyzed disorder was baby blues, whose symptoms are most intense between the third and the fifth day after childbirth. In the study group $(n=285)$, baby blues was diagnosed in $23.2 \%$ of the women. The result falls within the broad range of other authors' reports, both in Poland and worldwide. The results of the present study match those obtained by Reron and colleagues, whereby $21 \%$ of postpartum women obtained a positive result in the Edinburgh Postnatal Depression Scale [19]. Authors from Poznań estimated the frequency of occurrence of postpartum depression in postpartum women to be $22.5 \%$ [20]. However, results of studies conducted in Mexico were contradictory and suggested that baby blues happened very rarely $(1.8 \%)$ [21]. Data obtained during the second measurement, six weeks after childbirth, demonstrate that the analyzed mood disorder was postpartum depression, whose frequency of occurrence was estimated to be $17.3 \%$, although no statistically significant difference was found $(\mathrm{p}=0.12) .44$ women manifested symptoms of baby blues in the first week after childbirth. $41 \%$ of the cases $(n=18)$ developed postpartum depression in the sixth week after childbirth. Kirpinar and co-authors [22] examined women in the sixth week postpartum and estimated the frequency of occurrence of postpartum depression to 
be $17.7 \%$. Polish research studies reveal the odds ratio for postpartum depression in women to be at the level of $18.5 \%$. Depression indicators were rated using EPDS and BDI scales [23].

The analysis of mental disorders in postpartum women raises the question of what factors contribute to their occurrence. On the basis of the conducted logistic regression model it was concluded that: women with unfavorable economic situation had a twofold higher probability (2.56), women from families with a history of mental illnesses had a fourfold higher probability (3.87), and women dissatisfied with perinatal medical care had a fivefold higher probability (5.24) of suffering from baby blues. In the present study, $10.2 \%$ of women rated their financial situation as unfavorable. Therefore, it can be concluded that unfavorable financial situation is a predictor of postpartum mood disorders. However, Czarnecka and co-authors revealed contradictory data [20]. Research carried out in Australia on a group of 490 women eight weeks after childbirth stresses the significance of a history of psychiatric disorders in family for the development of postpartum depression [24], similarly as was found in the present study.

A woman's mood after childbirth is affected by numerous factors, and labor itself has a direct impact on how she will enter motherhood. It is worth emphasizing that proper care and correct attitude of medical personnel during labor has a positive influence on the mother. All parturient women are accompanied by medical personnel, it is therefore a good idea to document the effects of their work and introduce changes as necessary. Women may change their opinions concerning labor over time, having considered its positive and negative aspects. Such a mechanism may lie at the basis of a negative assessment of the course of labor and support of medical personnel. In a study conducted in the Opole province in 2005, researchers found that women who experienced negative emotions concerning labor had a significantly higher of postpartum depression. Mothers were also supposed to assess the perinatal medical care received in hospital. A majority of them had negative recollections of their labor and medical personnel. Many women stated that it was the worst and most humiliating moment of their life. The author of the said study inquires into the nature of the relationship between perinatal experiences and the level of postpartum depression: "Did the way medical personnel treated the woman influence her emotions after childbirth, or was it the woman's depressed mood that affected the way she rated the support received?'[25].

\section{CONCLUSIONS}

1. Baby blues was determined in every fourth woman from the sample group.

2. The risk for postnatal depression was found in $17.3 \%$ of women after six weeks postpartum.

3. The odds ratio for baby blues was affected by the following statistically significant factors: unfavorable financial situation of the women, genetic predispositions and dissatisfaction with perinatal medical care.

\section{REFERENCES}

1. Hanley J. Zaburzenia psychiczne w ciąży i połogu. Redakcja wydania I polskiego Sidorowicz S. Elsevier Urban\&Partner, Wrocław 2009.

2. Święcicki Ł. Depresje, obraz kliniczny, klasyfikacja, przyczyny. W: Pużyński S.(red.) Zaburzenia depresyjne w praktyce lekarza rodzinnego. Instytut Psychiatrii i Neurologii, Warszawa 2000,15-45.

3. Kmita G. Wybrane problemy psychologiczne u kobiet w okresie poporodowym. Pierwsze miesiące po porodzie typowe trudności. W: Chazan B. (red.) Położnictwo w praktyce lekarza rodzinnego. Wydawnictwo Lekarskie PZWL, Warszawa 1997,298-306.

4. Hopkins J, Marcus M, Campbell SB. Postpartum depression: a critical review. Psychol Bull.1984;95(3):498-515.

5. Brockington I. Postpartum psychiatric disorders. Lancet 2004;363(9405):303-310.

6. Reck C, Stehle E, Reinig K, Mundt C. Maternity blues as a predictor of DSM-IV depression and anxiety disorders in the first three months postpartum. J Affect Disord. 2009;113(1-2):77-87.

7. Dudek D, Siwek M, Zięba A, Nowak G. Depresja poporodowa. Przegl Lek. 2002:59(11):919-923.

8. Jaeschke R, Siwek M, Dudek D. Poporodowe zaburzenia nastroju - update 2012. Neuropsychiatria i Neuropsychologia 2012;7(3):113-121.

9. Yonkers KA, Smith MV, Brunetto WL, MPH, Cavaleri MA, LCSW. Rozpoznawanie depresji u kobiet zgłaszających sie do ginekologa. Ginekol Dypl. 2005;6(40):14-27.

10. Dubey C, Gupta N, Bhasin S. Prevalence and associated risk factors for postpartum depression in women attending a tertiary hospital, Delhi, India. Int J Soc Psychiatry 2012;58(6):577-580.

11. Fisher J, Tran T, La BT, Kriitmaa K, Rosenthal D, Tran $\mathrm{T}$. Common perinatal mental disorders in northern Viet Nam: community prevalence and health care use. Bull World Health Organ. 2010;88(10):737-745. 
12. Piotrowski T, Kaczyński J. Zaburzenia psychiczne związane z połogiem. W: Dębski R. (red.) Stany nagłe. Położnictwo i ginekologia. Medical Tribune Polska, Warszawa 2012, wydanie I, 262-269.

13. Howard LM, Flach C, Mehay A, Sharp D, Tylee A. The prevalence of suicidal ideation identified by the Edinburgh Postnatal Depression Scale in postpartum women in primary care: findings from the RESPOND trial. BMC Pregnancy and Childbirth. 2011;11:57.

14. Sit D, Rothschild AJ, Wisner KL. A review of postpartum psychosis. J Womens Health (Larchmt) 2006;15(4):352-368.

15. Bloom EA, Jansen PW, Verhulst FC, Hofman A, Raat H, Jaddoe VW, et al. Perinatal complications increase the risk of postpartum depression. The Generation R Study. BJOG 2010;117(11):1390-1398.

16. Mori T, Tsuchiya KJ, Matsumoto K, Suzuki K, Mori N, Takei N. Psychosocial risk factors for postpartum depression and their relation to timing of onset: The Hamamatsu Birth Cohort (HBC) Study. J Affect Disord.2011;135(1-3):341- 346.

17. Payne JL, MacKinnon DF, Mondimore FM, McInnis MG, Schweizer B, Zamoiski RB, et al. Familial aggregation of postpartum mood symptoms in bipolar disorder pedigrees. Bipolar Disord.2008;10(1):38-44.

18. Cox JL, Holden JM, Sagovsky R. Detection of postnatal depression. Development of the 10-item Edinburgh Postnatal Depression Scale. $\mathrm{Br} \quad \mathrm{J}$ Psychiatry 1987;150:782-786.

19. Reroń A, Gierat B, Huras H. Ocena częstotliwości występowania depresji poporodowej. Gin Prakt. 2004;12(3):32-35.

20. Czarnecka M, Jaszczak M. The prevalence and risk factors of depression in women postpartum. Archives of Perinatal Medicine 2006;12(3):7-10.
21. Romero-Gutièrrez G, Dueňas-de la Rossa EM, RegaladoCedillo CA, Ponce-Ponce de Leon AL. Prevalence of maternal sadness and its associated factors. Ginecol Obstet Mex. 2010;78(1):53-57.

22. Kirpinar J, Gözüm S, Pasinliöglu T. Perspective study of postpartum depression in eastern Turkey prevalence, socio-demographic and obstetric correlates prenatal anxiety and early awareness. J Clin Nurs. 2010;19(34):422-431.

23. Łukasik A, Błaszczyk K, Wojcieszyn M, Belowska A. Charakterystyka zaburzeń afektywnych u położnic w 1 tygodniu połogu. Ginekol Pol. 2003; 74(10): 1194-1199.

24. Johnstone SJ, Boyce PM, Hickey AR, Morris-Yatees $\mathrm{AD}$, Harris MG. Obstetric risk factors for postnatal depression in urban and rural community samples. Aust N Z J Psychiatry 2001;35(1):69-74.

25. Mendel A. Doświadczenie porodu a poporodowe obniżenie nastroju u kobiet. W: Lichtenberg-Kokoszka E, Janiuk E, Dzierżanowski J. (red.) Optymalizacja poroduzagadnienie interdyscyplinarne. Oficyna Wydawnicza Impuls, Kraków 2008, 65-69.

Address for correspondence:

dr n. o zdr. Marzena Kaźmierczak

Collegium Medicum w Bydgoszczy

UMK w Toruniu

ul. Łukasiewicza 1

85-821 Bydgoszcz

e-mail: marzena.kazmierczak@cm.umk.pl

telephone number: 52 585-59-04, +48506023541

Received: 26.04.2016

Accepted for publication: 30.06.2016 